\title{
Prevalence of Smoking among Young Pakistani Adults
}

\author{
Fizza Nasim ${ }^{1}$, SairaYousaf ${ }^{2}$, Rozina Arshad ${ }^{3}$, Bilal bin Younis ${ }^{4}$, Adeela Shahid ${ }^{5}$, Hafiza Rabia Naeem ${ }^{6}$ \\ Department of Medicine, Shalamar Medical and Dental College, Lahore ${ }^{1}$ \\ Sakina Institute of Diabetes and Endocrine Research, Shalamar Medical and Dental College, Lahore 2, 3, 4, 6 \\ Departement of Physiology Shalamar Medical \& Dental College Lahore ${ }^{5}$
}

\begin{abstract}
Background: The history of smoking tobacco is primitive and dates back to as early as $5000 \mathrm{BC}$. In the last century this has changed to different forms like cigarettes, filtered cigarettes, self-made cigarettes, tobacco in leaf (beery), hukka, sheesha and pipe.

Objectives: To explore tobacco smoking practices in young adults and the factors that influences them to initiate or quit smoking.

Methods: It was a cross sectional study based on a self-administered questionnaire with a sample size of 486. Study subjects were young adults. The age of participants was between 17 to 35 years. Data was collected after taking an informed consent and the individual confidentiality was maintained. A selfadministered questionnaire was given where questions were related to their socio-demographic characteristics and smoking behavior. The data was analyzed using SPSS version 20.

Results: Of the subjects who were interviewed almost $62 \%$ were smokers. Significant number of the people did not remember the age of smoking initiation. $97 \%$ of the subjects smoked manufactured cigarettes. $49.6 \%$ of smokers had to visit a physician in last 12 months but only $40 \%$ of them were counseled regarding smoking hazards and smoking cessation. $61.6 \%$ of people had not seen any information regarding hazards of smoking on any kind of media. Of those who noticed anti-smoking campaigns, $8.4 \%$ noticed them on print media, $27.5 \%$ saw them on electronic media and $2.6 \%$ noticed them on Bill board

Conclusions: The main determinants of regular smoking among the university students were male sex, lower education level and having friends who smoke. This calls for the implementation of sex and age specific anti-smoking policies. By assessing the smoking behavior in young adults, programs and policies can be designed with an aim to reduce smoking rates among the youth of our society.
\end{abstract}

\section{INTRODUCTION}

The history of smoking tobacco is very primitive and dates back to as early as $5000 \mathrm{BC}$. In the last century this has changed to different forms like cigarettes, filtered cigarettes, self-made cigarettes, tobacco in leaf (beery), hukka, sheesha and pipe. During the Second World War cigarette advertisements praising service members were widespread on popular radio programs and in periodicals. In these times of

\section{Corresponding Author:}

Dr. Fizza Nasim

Department of Medicine,

Shalamar Medical and Dental College, Lahore.

Email address: fizzanasimbutt@gmail.com

Received 09.05.19, Revised 22.06.19, Accepted 27.06.2019 stress smoking flourished even further. ${ }^{1}$ Moreover the "macho" image of the hardcharging, cigarette-smoking soldiers was idealized, promoting this menace in younger generation. In the recent past it was realized that there are number of side effects of smoking, the list is long and cumbersome and probably if we start writing the adverse effects of smoking it will cover the whole article. However, different cancers and cardiovascular diseases which form the majority of non-communicable diseases (NCD) can very clearly be attributed to smoking. ${ }^{2}$ If remained unchecked deaths related to it are projected to increase to 8 million by 2030 which accounts for $10 \%$ of all death. ${ }^{3}$ It is also noted in the recent past that this is more 
widespread in the females especially in the west. Differences in smoking behavior between women and men have decreased over time. ${ }^{4}$ In our country, smoking in the females is not very uncommon, however, still a social taboo. Lot of efforts worldwide is required to educate people regarding hazards of smoking. There is no significant work done on smoking in our country, therefore, there is a scarcity of data and the smoking patterns. We are still not sure whether it's more popular in urban areas or rural areas and which age group is more vulnerable to indulge into smoking. We are also not aware of the impact that existing anti-smoking campaigns have on the existing or potential smokers. Educating adolescents about the dangers of smoking in schools appears to be the most effective means of reducing adolescents' smoking susceptibility, although different prevention strategies may be necessary to ensure effectiveness for male and female adolescents. ${ }^{5}$

So far most of the campaigns are not directed towards these vulnerable population rather they address the smokers. It is noted that the awareness and education regarding hazards of smoking should begin at an early age; particularly among persons of low socioeconomic status. ${ }^{6}$ In this study we surveyed a specific group of population more extensively to identify the prevalence of smoking in young adults. By assessing the socio-demographic variations in smoking behavior, we can better target programs and policies aimed to reduce smoking rates among the adolescents.

\section{MATERIALS AND METHODS}

It was a cross-sectional study carried out by the department of medicine, Shalamar Medical \& Dental College Lahore. The sample comprised of 486 young adults, it included students and other young adults. Both male and female subjects between 17 to 35 years of age were included. Simple convenient sampling was done. Informed consent was taken from each participant. Questionnaire used to collect the data was adapted from global adult tobacco survey (GATS). ${ }^{7}$ The subjects were asked to fill out an anonymous questionnaire. Questions were related to their socio-demographic characteristics and smoking behavior. The data was entered and analyzed using SPSS version 20. Frequencies and percentages of the variables were calculated. Chi square test was applied to determine the association of smokers with the demographic factors. $\mathrm{p}<0.05$ was taken as significant statistically.

\section{RESULTS}

Baseline characteristics of the study population are shown in table 1.

Table 1: Base Line Characteristics of Study Population

\begin{tabular}{|c|c|c|c|}
\hline Characteristics & $\begin{array}{l}\text { Smokers } \\
\text { n (\%) }\end{array}$ & $\begin{array}{l}\text { Non-Smokers } \\
\text { n (\%) }\end{array}$ & $\begin{array}{l}\text { Total } \\
\text { n }\end{array}$ \\
\hline $\begin{array}{l}\text { Gender } \\
\text { Male } \\
\text { Female } \\
\text { Age } \\
\leq 20 \text { years } \\
\geq 20 \text { years } \\
\text { Education Level } \\
\text { Secondary School Completed } \\
\text { Graduation degree } \\
\text { Post-Graduation Degree } \\
\text { Work status } \\
\text { Government } \\
\text { Non-government employee } \\
\text { Self-employee } \\
\text { Student }\end{array}$ & $\begin{array}{l}306(100) \\
0(0.0) \\
46(15.1) \\
260(84.5) \\
112(36.6) \\
104(33.3) \\
90(29.4) \\
21(6.8) \\
25(8.1) \\
28(9.1) \\
232(76)\end{array}$ & $\begin{array}{l}177(98.3) \\
3(1.6) \\
98(54.4) \\
82(45.5) \\
02(1.1) \\
168(93.3) \\
10(5.5) \\
19(10.5) \\
15(8.3) \\
56(31.1) \\
90(50.0)\end{array}$ & $\begin{array}{l}483 \\
3 \\
\\
144 \\
342 \\
\\
114 \\
196 \\
100 \\
\\
30 \\
40 \\
84 \\
294\end{array}$ \\
\hline
\end{tabular}


Out of the 486 subjects who answered the questionnaire 483 males and only 3 females agreed to fill in the forms. Results showed that $63 \%$ of the males were smokers and $36 \%$ were non-smokers. Significant numbers $(84 \%)$ of smokers were more than 20 years of age. Of the non-smoker population $93 \%$ had a graduation degree and $5.5 \%$ were post graduates. In case of smoking population maximum percentage of smokers were under graduates $(36.6 \%)$ and graduate students (33.3\%). According to the work status $76 \%$ of the smokers were students of the university and rest of the $24 \%$ were either self-employed, government or non-government employees.

Table 2: Factors Influencing Smoking in Smokers

\begin{tabular}{|c|l|}
\hline Factors & n (\%) \\
\hline Age of initiation: & \\
$\leq 20$ years & $46(15.1)$ \\
$\geq 20$ years & $44(14.3)$ \\
Don't Remember & $216(70.6)$ \\
Influenced by: & \\
Friends & $120(39.2)$ \\
Family & $46(15.0)$ \\
Macho man & $96(31.3)$ \\
Social media & $44(14.3)$ \\
Product mostly used for smoking: & \\
Manufactured cigarettes & $298(97.3)$ \\
Hand-rolled cigarettes & $0(0.0)$ \\
Huqa/ Sheesha & $8(2.6)$ \\
Frequency of smoking: & $46(15.1)$ \\
Within 5 min & $110(35.9)$ \\
$\leq 60$ min & $150(49.0)$ \\
$\geq 60$ min & \\
&
\end{tabular}

Table 2 elaborates the data of smokers further. It was noted that $15 \%$ of the smokers initiated smoking below the age of 20 years; however $70 \%$ did not remember the age of initiation of smoking, $14 \%$ initiated smoking after the age of 20 years. The results showed that $39.2 \%$ of the students got influenced from friends and started smoking, 31\% influenced form Macho man and started smoking. As expected, $92 \%$ of smokers were smoking manufactured cigarettes. About $49 \%$ of the subjects responded that they have an urge to smoke after every one hour. $35 \%$ of the subjects smoked after the time interval of less than one hour.

Table 3: Health Care Center Visits and Efforts to Quit Smoking by Smokers

\begin{tabular}{|l|l|}
\hline Responses of smokers & n (\%) \\
\hline $\begin{array}{l}\text { Visited doctors or other health care } \\
\text { provider in past } 12 \text { months } \\
\text { Advised by doctors or other health } \\
\text { care provider to quit smoking in } \\
\text { past } 12 \text { months }\end{array}$ & $152(49.6)$ \\
$\begin{array}{l}\text { Tried to stop smoking in past } 12 \\
\text { months }\end{array}$ & $122(39.8)$ \\
$\begin{array}{l}\text { Noticed information and danger sign } \\
\text { about quitting smoking }\end{array}$ & $118(38.5)$ \\
$\begin{array}{l}\text { Print Media } \\
\text { Bill Board }\end{array}$ & $26(8.4)$ \\
Electronic Media & $8(2.6)$ \\
& $84(27.5)$ \\
\hline
\end{tabular}

When we asked smokers about visits to health care centers, $49.6 \%$ felt the need to see a doctor in recent past. It is interesting to note that a significant number of smokers i.e. $39.8 \%$ tried to quit smoking on self-help basis. There was a mix response in the subjects about the anti-smoking campaign. But it seems that most of the smokers put a blind eye to any such campaigns as only $38.5 \%$ admitted that they have noticed antismoking campaigns. People who had seen antismoking campaigns were further probed to look into the most influential medium. Out of those people who were aware of anti-smoking campaigns, it is interesting to note that $27.5 \%$ had seen this on the electronic media however, whether it influenced their smoking habit or not is quite obvious. Association of smokers with demographic variables is shown in table 5 . There was significant association of smoking with age, education level and work status 
Table 5: Association of Smokers with Demographic Variables

\begin{tabular}{|l|l|l|l|}
\hline Variables & $\begin{array}{l}\text { Smoker } \\
\mathbf{n = 3 0 6}\end{array}$ & $\begin{array}{l}\text { Non- } \\
\text { Smoker } \\
\mathbf{n = 1 8 0}\end{array}$ & $\boldsymbol{\chi}^{2} / \mathbf{P}$ \\
\hline $\begin{array}{l}\text { Age } \\
\leq 20 \text { years } \\
\geq 20 \text { years }\end{array}$ & $\begin{array}{l}46 \\
\text { Education Level }\end{array}$ & $\begin{array}{l}98 \\
82\end{array}$ & $84.4 / 0.001^{*}$ \\
$\begin{array}{l}\text { Secondary School } \\
\text { Completed }\end{array}$ & 112 & 02 & \\
$\begin{array}{l}\text { Graduation degree } \\
\text { Post-Graduation }\end{array}$ & 90 & 168 & $163.5 /<0.01^{*}$ \\
Degree & 10 & \\
\hline $\begin{array}{l}\text { Work status } \\
\text { Government } \\
\text { Non-government } \\
\text { employee }\end{array}$ & 21 & 19 & $20.96 / .07^{*}$ \\
$\begin{array}{l}\text { Self-employee } \\
\text { Student }\end{array}$ & 28 & 15 & \\
\hline
\end{tabular}

Chi square test applied and $p$ value $<0.05$ is taken as statistically significant

\section{DISCUSSION}

Most of the people have known that cigarettes are notorious for causing lung cancer but the list of diseases and cancers caused by them are much higher in number since they contain 4000 chemical compounds and 400 toxic substances. ${ }^{8}$ The present study examined the smoking status among a sample of students and employees in young adults resident of Lahore, Pakistan. The prevalence of smoking in the university in which this study was conducted was found to be $62 \%$ which was similar to earlier studies conducted in universities of Peshawar and Islamabad. ${ }^{9}$ ${ }^{10}$ The high prevalence among students is particularly concerning given that rates are typically higher among less educated populations. Our finding is consistent with other studies conducted in Middle Eastern region reporting that the most common age for smoking initiation was between 15 and 19 years. ${ }^{11,12}$ However most of the smokers didn't even remember the age of smoking initiation. Most commonly used mode of tobacco smoking was found to be a manufactured cigarette which is contrary to a study conducted in universities of Islamabad and Middle East where sheesha smoking is more popular. ${ }^{13,14}$ This can be attributed to higher economic status of the students interviewed in these universities as compared to the university of Lahore. We found that the predictors of smoking regularly were male sex, smoking of family and friends, lower education status and social media. Specifically, the smoking status of parents, siblings and peers is related to the smoking habits of young adults. There was some degree of influence from family and social media but $39.2 \%$ of the influence came from friends. This suggests that efforts to increase the number of smoke free homes and educational institutions may be warranted.

It was also noticed that even at a younger age around $50 \%$ of smoker found a need to visit a health care professional in past 1 year which is an alarming percentage. An important point to note is that only $49.6 \%$ of the smokers were encouraged to quit smoking by their health care professionals. This is contrary to a study conducted in USA where more elaborate clinical guidelines are present for the physician according to which physicians provide tobacco cessation interventions to their patients who are smokers at every visit. ${ }^{15}$ The concerned health departments, especially the health care providers are ignorant of their role in creating awareness among these people regarding the hazards of smoking and the options available to help them quit. According to our study only $38 \%$ of the students had noticed anti-smoking campaigns and only electronic media had a major impact. This in contrast to earlier study carried out by Sobaniet al, where graphic health warnings were considered to be most effective. This can be due to increasing popularity of social media among adolescents, therefore social media can be used a powerful medium to create awareness regarding smoking hazards and smoking cessation programs. Results from the study suggest that Framework Convention for Tobacco Control 
(FCTC) provisions calling for more smoking cessation treatments and smoke free spaces will be very effective within Pakistani universities. Smoking cessation is an important health priority world-wide and for individual smokers, who otherwise suffer a $50 \%$ chance of dying prematurely due to smoking. ${ }^{16}$ It is high time that we not only make appropriate strategies but also carry out the continuous surveillance of the implementation as well. This calls for the implementation of sex and age specific antismoking policies. To help smokers to quit successfully, effective smoking cessation plans are of vital importance.

\section{Limitations}

Very small number of female consented to participate in the present study, so the study does not predict the smoking behavior among females. The current study involved cross sectional data which identified the potential relationship between different smoking behaviors, however the causal relationship could not be assessed.

\section{CONCLUSION}

In conclusion, the main determinants of regular smoking were male sex, lower education level and having friends who smoke. This calls for the implementation of sex and age specific antismoking policies. By assessing the smoking behavior, target programs and policies can be developed with an aim to reduce smoking rates among the youth of our society. There is a need for training programs for health professionals and educational campaigns for opinion leaders, teachers, and the public. The study lays an important foundation for future research. Further studies should be planned and conducted to further understand the smoking behavior of the young people in Pakistan.

\section{Conflicts of Interest}

The authors declare no conflict of interests.

\section{Contributors}

Dr. Fizza Nasim conceived and designed the study, Dr. Saira Yousaf drafted the initial version of the manuscript, revised the manuscript for intellectual content. Dr. Rozina Arshad contributed to the literature search and discussion of the article. Prof. Bilal Bin Younis critically reviewed the manuscript and provided substantial input to all the sections of manuscript. Hafiza Rabia Naeem entered the data and help in statistical analysis. Prof. Adeela Shahid performed and reviewed the statistical analysis and approved the final version of the manuscript.

\section{REFERENCES}

1. Conway TL. Tobacco use and the United States military: a longstanding problem. Tob Control. 1998; 7: 219-21.

2. Ordóñez-Mena JM, Schöttker B, Mons U, Jenab M, Freisling H, Bueno-de-Mesquita B, O'Doherty MG, Scott A, Kee F, Stricker BH, Hofman A. Quantification of the smokingassociated cancer risk with rate advancement periods: meta-analysis of individual participant data from cohorts of the CHANCES consortium. BMC medicine. 2016; 14(1): 6265.

3. Naseem S, Khattak UK, Ghazanfar H, Irfan A. Prevalence of non-communicable diseases and their risk factors at a semi-urban community, Pakistan. Pan Afr Med J. 2016; 23: 151.

4. Peters SA, Huxley RR, Woodward M. Do smoking habits differ between women and men in contemporary Western populations? Evidence from half a million people in the UK Biobank study. BMJ open. 2014; 4(12):e005663. doi: 10.1136/bmjopen-2014005663.

5. Ahmed R, Rizwan-ur-Rashid MP, Ahmed SW. Prevalence of cigarette smoking among young adults in Pakistan. J Pak Med Assoc. 2008; 58(11): 597-601.

6. Bhanji S, Andrades M, Taj F, Khuwaja K. Factors related to knowledge and perception of women about smoking: a cross sectional study from a developing country. BMC women's health. 2011; 11(1):16. doi: 10.1186/14726874-11-16. 
7. Global Adult Tobacco Survey (GATS). World Health Organization 2009. Available from https://www.who.int/tobacco/surveillance/gats _rep_egypt.pdf. Accessed on 10 February 2019.

8. Chaudhry MA, Ashraf MZ. Trends of Tobacco Smoking Among Students of Private University, Lahore, Pakistan. APMC 2014; 8(1): 16-20.

9. Zaman M, Irfan U, Irshad E. Prevalence of cigarette smoking among Peshawar University students. Pak J Chest Med. 2002; 8: 9-18.

10. Shaikh MA, Kamal A. Prevalence and pattern of smoking in university students--perspective from Islamabad. JCPSP. 2004; 14(3): 194-98.

11. Al-Turki YA. Smoking habits among medical students in Central Saudi Arabia. Saudi Med J. 2006; 27(5): 700-3.

12. Haddad LG, Malak MZ. Smoking habits and attitudes towards smoking among university students in Jordan. Int J Nurs Stud. 2002; 39(8): 793-802.
13. Tariq N, Rizvi F, Rajput AM, Khan A, Afzal M. Frequency and common forms of smoking in female students of universities of Islamabad. Isra Med J. 2013; 5(2): 144-7.

14. Champassak SL, Catley D, FinoccharioKessler S, Farris M, Ehtesham M, Schoor R, Goggin K. Physician smoking cessation counseling and adherence to a clinical practice guideline. Eur J Pers Cent Healthc. 2014; 2(4): 477-84.

15. Sobani Z, Nizami S, Raza E, Khan JA. Graphic tobacco health warnings: which genre to choose? Int J Tuberc Lung Dis. 2010;14(3): 356-61.

16. Zawahir S, Omar M, Awang R, Yong $\mathrm{HH}$, Borland R, Sirirassamee B, Fong GT, Hammond D. Effectiveness of antismoking media messages and education among adolescents in Malaysia and Thailand: findings from the international tobacco control south East Asia project. Nicotine Tob Res. 2013; 15(2): 482-91. 